\title{
KDR Gene
}

National Cancer Institute

\section{Source}

National Cancer Institute. KDR Gene. NCI Thesaurus. Code C24532.

This gene plays a role in angiogenesis and vascular regulation. 